\title{
図学教育史の落穗拾い（1 ）*
}

原正 敏**

『図学研究』第 5 号・7号・8 号に, 幕末から明治初期にかけての図学教育について書き, 70年度大会で「旧制高等学校における図学教育」を発表したが, その後図学と縁遠い職につい てしまい，多忙さにかまけて誌上に発表するところまでいかない状態である。この間，旧制高 校出身（と思われる）会員には御出身高校の図学教育に関する情報についてアンケートをお願 いし，多くの方々の御協力をえたにもかかわらず，まだまだまとめきらず，申し訳けなく思っ ている。誌上を借りてお礼とお詫びを申上げる次第。図学教育からははなれていても図学教育 史についての関心は決してなくなっておらず，断片的な資料や情報を追いつづけている。「落 穂拾い」といったことは，私の予定している図学教育史研究の当面の計画（明治初期の困学教 育 (III), 旧制高等学校の図学教育, 初等中等教育における図学教育) を終ってから付加すべき なのだが，上述の計画完遂はだいぶ先になりそうなので，これまで書いたものの補足と訂正の 意味をこめて若干のコメントをさせてほしいと思う。なお，新制大学発足時における図学関係 者の対応（授業時間数の縮小と教材選定，人事問題など）については, 当時を教官として経過 された「長老」会員諸氏に，全国的状況のまとめでなくても，個々人の身辺の回想録の形でで も，是非本誌上に残しておいていただきたい。

佐竹曙山の透視図本誌第 5 号で，西洋画の描法を取り入れた画家として，平賀源内，司 馬江漢, 小田野直武, 佐竹義敦 (曙山), 亜欧堂田善, 渡辺華山の名をあげたが, 佐竹曙山遺品 の写生帳（奈良恭三郎氏所蔵）の中に円と正八角形の透視図が描かれていることには言及しな かった。写生帳は三冊で, このうちの一冊には冒頭に佐竹曙山自筆の「画法綱領」が和文で, 次に「画図理解」が漢文で書かれ, そのあと「丹青部」の項で絵具の顔料や油絵具の製造法が 記されている。「丹青部」のあとに遠近法の説明図（臨之図，望之図），透視図（看斜平円之法， 看斜八法之法), 幾何画法 (画八方之法, 看破円画偏円之法), らせん階段の直投象図などが 8 頁にわたって描かれ，そのあとに 6 枚の外国製銅版画が貼付され，さらに後述の「裸婦困」を 含む帆船・干魚などの絵が続いている。1)

佐竹曙山（1748～85）は秋田藩主佐竹義明の長男として江戸の藩邸で生まれ，11歳で藩主を つぎ18歳のときお国入りしている。江戸で，または入国後，平賀源内と知り合い，源内から直 接に, または藩士小田野直武 (『解体新書』の挿絵を描いた) を通して, 源内から西洋画の知識 をえたものである。”曙山の写生帳にある「裸婦図」はGerard de Lairesse の G root Schilder boek, waar in de Schilderkonst, in al kaar deelen grondig werd onderweezen, ook door Redeneeringen en Prentverbeeldigen verklaard,1727, 所載の23頁の図と全く同一で あり，曙山が Lairesse の書の図を摸写したものと推定される。現在この書の1740年版が神戸 市立南蛮美術館に所蔵されているが，同じくこの「裸婦図」を載せている森島中良の『紅毛雑 話』(1787年刊)の図より曙山の図のほうが原図に忠実で，曙山の図を森島が摸写することはあ クえても，その逆は考えられない（曙山は1781年頃からほとんど絵をかかず1785年に没してい る)。したがって曙山が Lairesse の画法書を手もとに置いていたとみるのが至当であろう。曙 山の遠近法の説明図（臨之㘡，望之図）と同じ困は Lairesse の画法書にないが，該書では消 点（光線の消点をも含めて）は明確に意識化されており，それが強調されているので, 曙山が

* 昭和50年 1 月 11 日受付

** 北海道大学教育学部 
この書から「臨之図」や「望之図」を描くことは十分可能であろう。この遠近法説明図の次に ある「看斜平円之法」「看斜八方之法」は，これまで美術研究家の関心を呼んでいないが，わ れわれには非常に興味深いものである。図 1 , 図 3 は曙山の写生帳の図をそのままに（相対位 置, 長さの比などを同一に）描いたものであり, 図 2 , 図 4 は現在の標準的図学教科書にある 作図例にしたがって描いたものである。「看斜平円之法」では距離点が明示されておらず，対 角線の透視㘡をどうして描い たか判らないが,「看斜八方 之法」では距離点が明示され ている。「距離点法では, 視 点の平面図停点 $\mathrm{s}$ を直接に 使用しないので, これを省略
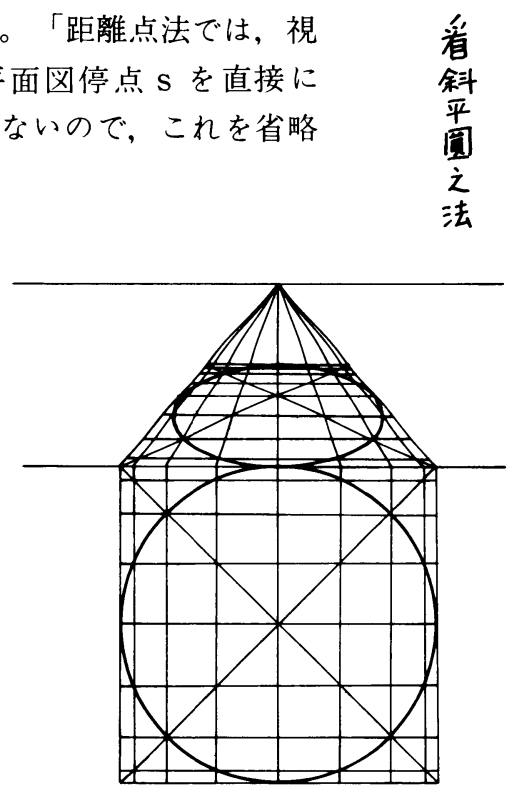

図 1

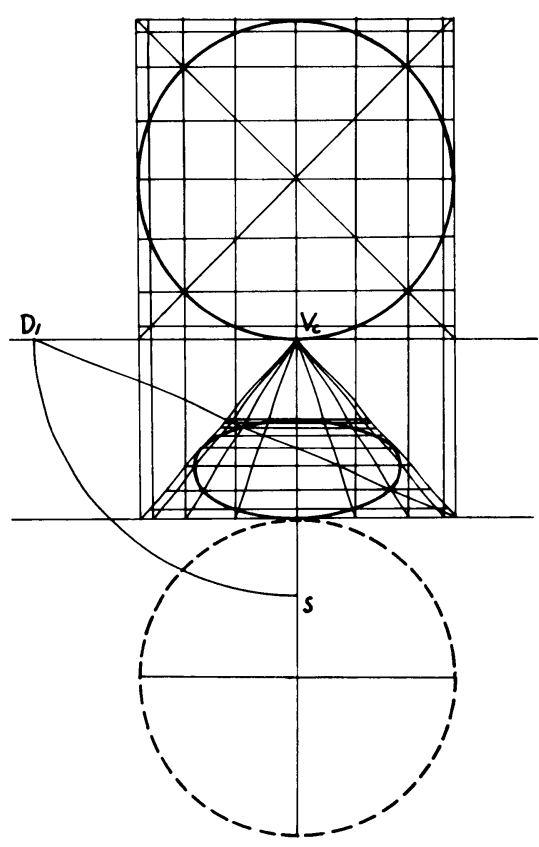

図 2

するのがふつうである。また平面図を裏がえして，破線で示した位置に与えることもある」が， 曙山が視点（視高・視距離）や距離点の概念を理解した上で作図したとは思われない。恐らく 摸写した原図が存在したに違いない。前述の Lairesse の画法書は Schilder konst 即ち Art of painting の書で, 透視図法の理論的な説明は全く載せられていないので，曙山はこれとは 別の画法書をみていると考えるのが至当である。ところで, 先年小林文次氏（日大理工学部教 授）が，曙山の写生帳の遠近法説明図や透視図の末尾（8頁目）にある「らせん階段の直投 象困」と全く同一の図がJoseph Moxon (1627 1700) 著の Practical Perspective, 1670, の第35図にあることを突きとめられた。3) 小林氏のお話によれば, Moxon の原図と曙山の写生帳 の図は紙の伸縮の誤差範囲内でぴたりと一致し，さらには写生帳の図にはピンニングした穴 が認められるという。” この時期に英書が舶載されていたとはまず考えられないので, この本の 蘭訳書ないしは Moxonの第35図と同じ図を載せた蘭書が介在していたとみるのが妥当であろ う。写真製版のなかった時代のことだから, 蘭訳書などの場合, 原寸のまま原図が他に転載さ れることのほうが多かったとみてょいであろう。Moxonの書は実用的な透視図法を解説した ものであるから，当然のこととして三角形・四角形・六角形・六角形・八角形・円などの透視 図が例示されているが, 曙山の図とぴたりと一致するものはない。図 5 , 困 6 は Moxonの図 で, 曙山の困にもととも近いもののコピーである。曙山が透視図法に精通しておれば，Moxon 
の図例をもとにして写生帳の図（図1，図３）を描くことも可能であるが，曙山が透視図法に ついてそれほど深い理解をもっていたとは考えられない。恐らく写生帳の図と全く同じ図例を 載せた蘭書があって，それを摸写したものと思われる。その蘭書としては，Lairesse のもう

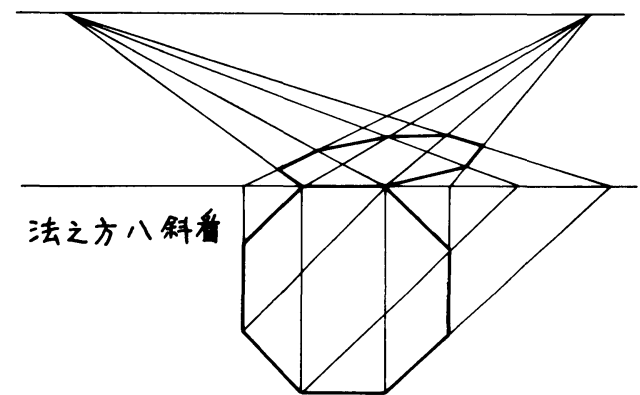

图 $\quad 3$

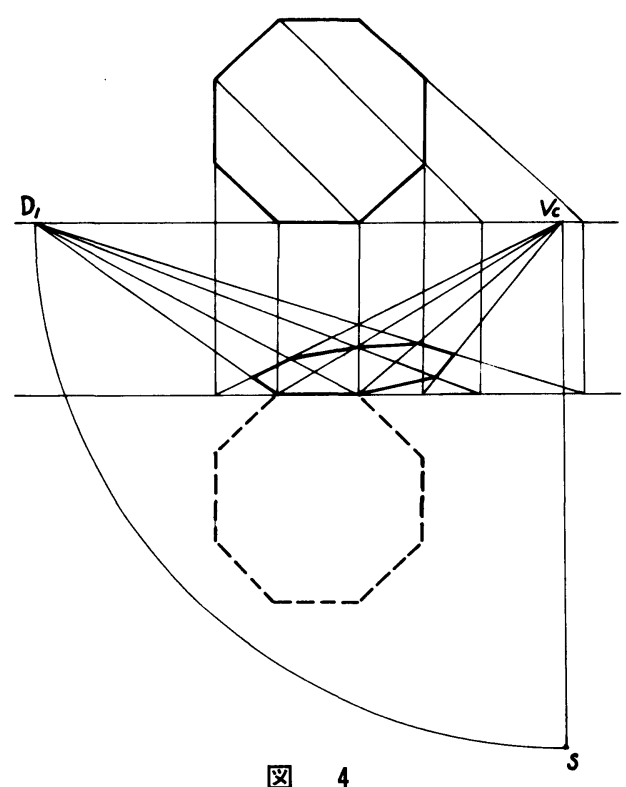

図 4

一つの著書, Grondleggingen der teekenkunst, zijnde cen kort en zekere weg om door middle van geometrie of meetkunde de teekenkunst volkomen to leeren, 1764,

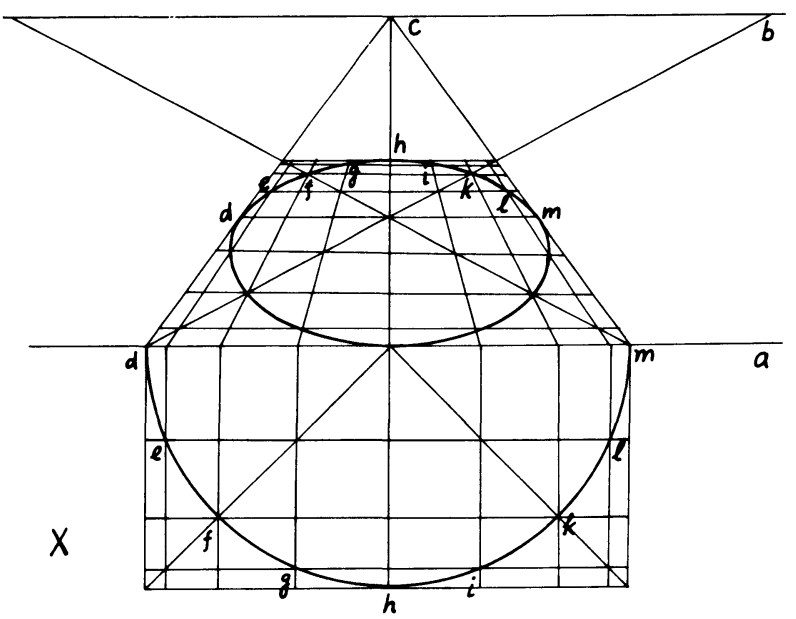

図 5

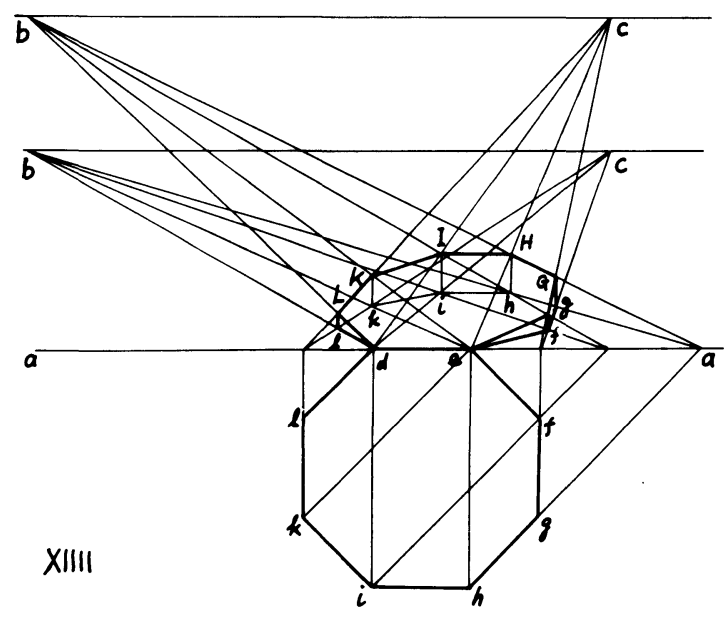

図 6

の可能性が大きいが，まだ現物を見る機会をえていない。この書について古賀十二郎氏は「こ の書は，幾何学の助けによって，画学を大成するために，捷径たり，且つ確実なる方法たるべ 
き要綱を説いたもので……ちらくこの書もまた長崎に舶斉されたことであろう」と述べてい る。古賀氏の見たのが古賀氏自身の蔵書であったのか，何処か公共の図書館所蔵のものか不明 だが, 所在が判ることを顧ってやまない。曙山の写生帳にある透視図は，それが完全な摸写だ としても，日本人の描いた正確な透視図のもっとも古いものの一つだといってよかろう。

なお，司馬江漢もはじめ平賀源内の指導によって西洋画への関心を媣くしたと考えられるが， 西洋画の技法については，江漢は曙山の部下であり絵の友であった小田野直武から直接指導さ れたと思われる。江漢の著述に散見される画論は，たぶんに「画法綱領」や「画図理解」に近 いから，曙山のこの著述のなった安永 7 年（1778） 9 月以降，直武が江戸にあった翌年冬まで の間に二人の接触があったと推定される。本誌第 5 号に, 江漢が天明 8 年 (1788) 長崎来遊の 折，オラン名商館長 Titsingh よりコンスト・シキルト・ブークを手に入れたというのは虚偽 の記述だといわざるをえないと記したが，細野正信氏は「諸要件から考え合わせると江漢が千 ッシングル会ってコンスト・シキルド・ブークを贈られたのは安永 8 年 $(1779)$ のことではな かと思われる」゙ と述べ, 成瀬不二雄氏は「曙山も中良も, 源内から洋画の知識を得ているので, 源内がライレツセの画法書を所持していた形跡が濃いつと述べている。源内ならびに彼と交遊 のあった三人（佐竹曙山，森島中良，司馬江漢）のいずれもが所持するほどの冊数のライレッ セ画法書が舶載されていたとは考えられないが，この書が安永・天明の頃（1772～1788）江戸 の蘭学者仲間に知られていたことは間違いない。

多賀章人と杉重敏・花和安年、図学研究」第 7 号では, 多賀章人について「どこでどう いう教育を受けて東京大学の教官になったのか今のところまだはっきりしない」彼がいつ英国 に渡ったか判っていない」と述べたが，その後次のような事実が判明した。即ち1872年の『官 員録』に工部省灯台恭技術一等見習としてはじめて名前が出ている。73年 1 月，灯台技術の研 究のため，工部省から英国に派遣され，翌74年 6 月に帰国している。 1874年の『官員録』には 灯台昚技術一等見習上級として出ているが，75年以降の『官員録』からは名前が消えている。 恐らく1875年に開成学校に移ったものと思われる。

杉重敏については，『図学研究』第 8 号で「杉は明治初期にいち早く図法幾何学を教授した 日本人として，東京大学の多賀章人，小島憲之に匹敵する大きな役割を果したのであるが，今 のところ彼の経歴ならびに工部大学校廃止後の消息は全く判っていない」と記したが，杉は多 賀と同じく1872年の『官員録』に灯台患技術一等見習として出ている。74年版では多賀が技術 一等見習上級なのに対し，杉は技術一等見習下級となっている。杉は75年 3 月に工学寮二等少 手になっているが, 恐らくこの時期に工学寮工学校の助手になったものと思われる。その後 1877年に工学校が工部大学校となり，工部省工作局の所轄となったが，彼は工作局六等技手補 をへて78年 5 月には六等技手二級になっている。ところが79年12月改の『官員録』では六等技 手に杉重敏の名はみえず，杉甲一郎の名が出ている。杉重敏と杉甲一郎が同一人物であるとい う確証はないが，いずれも工作局六等技手で，本籍も同じく山口県であること，そして，1878 年以前の『官員録』には杉甲一郎の名前がみえず，逆に79年以降のそれには杉重敏の名前がみ えないので，改名したとみるのが妥当であろう。その後，杉甲一郎は1882年 1 月に工作局三等 技手となり, 同年 9 月 8 日工部大学校教授に昇進, 同年 12 月から約 6 力月学術研究のため私費 で米国に渡航している。 1884 年 2 月改の『官員録』には工部大学校教授として杉甲一郎の名前 が出ているが，85年以降の『官員録』からは名前が消えており，現在までの調査ではその後の 消息は全くつかめない。恐らくこの頃死去したのではあるまいか。なお 85 年 4 月改正の「工部 大学校学課並規則」の日課表には, 予科および専門学科の図学担当者として杉の名前（姓のみ 記載）がでている。

花和安年の名前が文献の上ではじめて出てくるのは1877年 3 月改正の「工部大学校学課並諸 
規則」で，同僚の杉重敏とともに図学担当の助手となっている。『官員録』に名前が出てくる のは1883年からで，同年の『官員録』では工部大学校八等属, 翌年 2 月改の『官員録』では大 学校助教授・八等属とあり，1885年および86年のそれでは助教授・判任, 本籍静岡と記載され ている。花和はその後, 1888年 2 月, 築地に工手学校が開設されると同時に, 同校土木科およ び子科の教授となって主として製図を担当した。さらに1909年, 彼の親友松本小七郎の要請で 中央工学校の設立発起人となって設立準備に加わり, 同年10月21日設立認可とともに初代校長 に就任した。1911年 1 月勇退し，1925年逝去した。”)

註 1 ) 成瀬不二雄『曙山・直武』33〜34頁，6〜 7 頁，16２0頁，1969年 三彩社。なお， 本稿の図 1 , 㘡 3 は成瀬氏からいたな゙いた同氏撮影の写真をもとにしたが, 写生帳はじめ曙 山の全作品は1974年末, 三一書房刊行の太田桃介, 武塙林太郎, 成瀬不二雄共著『図録 秋田蘭画』におさめられている。

2 ) 須藤利一『困学概論〔新版〕』204頁 1961年 東大出版会

3 ）『朝日新聞』1972年11月20日夕刊

4 ）1974年 8 月 5 日 小林文次氏よりうかがった話。本稿図 5 , 困 6 は, Columbia 大学 の Avery Library の厚意により小林氏が入手されたマイクロフィルムを小林氏の御好 意で引伸していただいたものの摸写である。

5）古賀十二郎『長崎絵画全史』128頁，1944年

6 ) 細野正信『司馬江漢』 71頁, 1974年 読売新聞社

7 ) 成瀬不二雄 前出書 34 頁

8 ) 大蔵省編『工部省沿革報告』1888年, 日本科学史学会編『日本科学技術史大系』

第 8 巻（教育 1 ） 344頁，1964年による。

9 ) 旧工部大学校史料編纂会『工部大学校史料』146頁 1931年

10）『中央工学校 六十年史』35頁 1971年 